\title{
K výzvám společnosti vědění adresovaným škole
}

\author{
Petra Valentová \\ Vysoká škola ekonomická v Praze, Fakulta mezinárodních vztahů, Katedra německého jazyka
}

Redakci zasláno 3. 9. 2012 / upravená verze obdržena 8. 3. 2013 / k uveřejnění přijato

9. 32013

\begin{abstract}
Abstrakt: Společnost vědění - termín označující mnoho teoretických přístupů $\mathrm{k}$ pochopení naší současnosti se stal rovněž součástí mnoha veřejných dokumentů. Studie naznačuje charakteristické znaky, které naše současnost vykazuje a které její označení coby společnost vědění opravňují, pozastavuje se u názorů společenských kritiků, zamýšlí se nad nově definovanou rolí člověka v pracovním světě a naznačuje některé důsledky, které $\mathrm{z}$ konceptu společnosti vědění vyplývají pro školu. Autorka naznačuje nutnost změn ve směru k otevřenosti školy coby instituce, $\mathrm{k}$ otevřenosti kurikula, interdisciplinaritě, internacionalitě, nově definované roli učitele atd., současně však upozorňuje na odpovědnost společnosti vůči škole, nebot' škola je ve společnosti vědění sice ústřední institucí, nepožívá však vždy tomu odpovídající vážnosti.
\end{abstract}

Klíčová slova: společnost vědění, výchova a vzdělávání, škola, nová role učitele

\section{1 Úvodem}

Každá doba obvykle dostává svá přízviska, filosofové, sociologové a další teoretici hledají signifikantní rysy, které ovlivňují společenské dění a činí ze současníka typ odlišný od typu předcházejícího. Tato kategorizace je odvěkou lidskou snahou zachytit podstatné, nahlédnout a uchopit skutečnost alespoň v některých jejích rysech, když je ve své komplexnosti evidentně bezbřehá a neuchopitelná, dále pak snahou vymezit se vưči éře předcházející, která je považována za přežitou a $\mathrm{v}$ určitých rysech dramaticky odlišnou. $\mathrm{V}$ historii se opakovaně setkáváme se snahou zasadit sebe a svoji dobu do dějinného rámce, a ačkoliv je zřejmým cílem této snahy vymezit se vůči minulému, současně se takto deklaruje lidská touha po kontinuitě s předky. Stejně jako oni se i my snažíme stát součástí onoho dějinného celku, což je však možné až tehdy, když si dáme nějaké jméno a staneme se součástí dějepisu - př́iběhu, který o sobě nejprve sami píšeme a posléze je o nás psán jinými. Lidsky pochopitelnou je také snaha vidět se v hezkém světle v naději, že ono světlo a jas na nás ulpí i pro oči generací př́íších. 
Jedním z mnoha označení pro dnešní společnost odkazujících však k týmž podstatným znakům je tedy poněkud vzletné označení společnost vědění (knowledge society, Wissensgesellschaft) ${ }^{1}$. Termín společnost vědění bývá vymezován vưči termínu industriální společnost, který má nahrazovat. Pojmu společnost vědění se v tomto článku přidržíme, ačkoliv skrývá určitá úskalí. Pokusíme se nastínit, kterými rysy naší současnosti je dle našeho názoru oprávněn, ač jsme si vědomi, že je možno ho považovat za zavádějící, nejasný, či dokonce překonaný (srov. Veselý, 2004, s. 439-445) nebo, na což chceme také upozornit, v některých kontextech vyprázdněný či ideologický.

Označení společnost vědění je ve vědních oborech stále živé a velmi rychle se stalo i proklamativní složkou mnoha sfér lidského života a vstoupilo do četných dokumentů (Mezi dokumenty mezinárodních organizací uved'me např. Knowledge management in the learning society (OECD, 2000), Towards knowledge societies (UNESCO, 2005), mezi českými pak např. Národní program rozvoje vzdělávání v ČR. Bílá kniha (2001), Strategie rozvoje lidských zdrojů pro Českou republiku (2003), Bílá kniha výzkumu, vývoje a inovací $v$ České republice (Klusáček, Kučera, \& Pazour, 2008) aj. Logickým důsledkem pak je, že neustále opakované označení začne žít vlastním životem, stává se ideologií a zpětně pak mnoho sfér lidského života ovlivňuje, určuje a vytváří dokonce jakýsi nárok či závazek, aniž by bylo skutečně jasné, co se vlastně žádá. Škola je, dalo by se říci, první na ráně, což zakládá nutnost se tímto problémem zabývat a často proklamativní a ideologické výzvy naplnit konkrétním obsahem.

Cílem této studie je nastínění charakteristických rysů společnosti vědění, jejích možností a úskalí, dále pak výzev, které z charakteru společnosti vědění vyplývají pro školu, jaké nároky se v nových podmínkách současné globalizované společnosti utvářejí, jak škola a učitelé těmto nárokům doposud čelí.

1 Termín společnost vědění není v českém kontextu ještě ustálen, ve stejném či podobném významu bývá užíváno ještě termínů znalostníspolečnost, společnost založená na vědomostech, společnost poznání, informační společnost. Přimlouváme se za pojmové sjednocení a razíme termín společnost vědění, nebot’ lépe koresponduje s termínem německým a vyhovuje nám širší význam slova, který zahrnuje významy slov poznání i znalost, respektive vědomost. Kopecký $(2009$, s. 39) poukazuje na to, že vědění je oproti pojmu informace vázáno na člověka a umožňuje mu jednat. Vědění lze dělit na explicitní, které lze snadno zachytit slovy či obrazy a také ho lze snadno zprostředkovat, a vědění implicitní - Švec (2009) hovoří o tacitních znalostech, které jsou zprostředkovatelné jinými způsoby - zkušenostním učením, sdílením. Implicitní znalosti mají blízko k praxi a jedním z charakteristických znaků společnosti vědění je fakt, že význam těchto znalostí narůstá. 
Dalším cílem je pak poskytnutí zevšeobecňujícího pohledu, který by mohl posloužit jako základ pro pohled do budoucna, pro hledání konkrétních řešení ve specifických oblastech školství a měl by rovněž posloužit jako podnět pro společenskou diskusi o vztahu společnosti, která sebe samu nazývá společností vědění, ke škole, své ústřední instituci, a učitelům, klíčovým aktérům společnosti vědění.

\section{Koncept společnosti vědění a společenští kritici}

Pojmu společnost vědění mezi prvními použil ekonom Peter Drucker, který je také považován za jednoho ze zakladatelů konceptu společnosti vědění, v práci The age of discontinuity (1969). Koncept popularizoval sociolog Daniel Bell ve studii The coming of post-industrial society (1973). Pojmu společnost vědění bývá užíváno často bez dalšího vymezení jakožto metafory, jako jakéhosi ideálu, k němuž máme nakročeno, bývá exaktně vymezován, konstatován coby stav nebo se setkáváme s pojmy synonymickými (znalostní společnost atp.), respektive s koncepty př́buznými (postindustriální společnost, učící se společnost atp.). S pojmem společnost vědění nadále pracuje současná vzdělávací politika, pedagogika (např. Rüschoff \& Wolff, 1999; Maňák, 2009), sociologie (např. Veselý, 2004), filosofie (např. Liessmann, 2008) i ekonomie (např. Klein, 1998), v úvahách o dalším směřování školy ho tudíž nelze opominout, a to i bez ohledu na výše zmíněný fakt, že se pojem společnost vědění (či některý ze synonymních pojmů) stal součástí mnoha dokumentů týkajících se školy bezprostředně, jako je například Národní program rozvoje vzdělávání v ČR. Bílá kniha (2001), Národní programy reforem $\check{C}^{2}$, Dlouhodobý záměr vzdělávání a rozvoje vzdělávací soustavy v ČR (2007), Bílá kniha terciárního vzdělávání (Matějů et al., 2009).

\subsection{Vědění coby ekonomický zdroj}

Vymezme si nyní konkrétněji hlavní rysy společnosti vědění. Rozhodujícím ekonomickým zdrojem ve společnosti vědění již není kapitál, jak tomu bylo ve společnosti industriální, ale vědění ${ }^{3}$. Dủkazem změny paradigmatu jsou dnes již dobře známé příběhy závratného zbohatnutí založeného na vědění, jako např́íklad př́běh zakladatele sociální sítě Facebook Marka Zuckerberga,

\footnotetext{
Například Národní Lisabonský program 2005-2008 z října 2005 a Národní program reforem České republiky 2008-2010 z ř́ina 2008.

3 Vědění zde definujeme jako souhrn veškerých informací a know-how, jimiž lidstvo v danou chvíli disponuje.
} 
za jehož ekonomickým úspěchem stál pouze dobrý nápad. Vyrábí se stále více výrobků z malého množství levných surovin, pro jejichž výrobu i obsluhu je však potřeba stále většího know-how - něčeho nehmotného, co však tvoří největší část jejich tržní ceny. Klíčovým výrobním faktorem se tedy stává vědění.

Např:: Veselý (2004) o společnosti vědění ř́ká:

... zatímco základními konstitutivními prvky moderní společnosti byl fyzický kapitál, množství lidské práce a průmysl (odtud pak pojmenování „průmyslová“ nebo „kapitalistická" společnost), v současné době jsme svědky transformace ve společnosti, ve které se klíčovým faktorem produkce stává vědění, důsledkem čehož se následně zásadně mění i veškeré společenské instituce. (s. 434)

Vědění je základem konkurenceschopnosti a úspěchu. Informace lze vyměňovat levně a rychlost přenosu dat neustále narůstá. Čas a prostor nejsou v současné době determinujícím faktorem. Důsledkem je vznik nadnárodních společností a s tím spojená internacionalizace vědění. Vědění se produkuje, zprostředkovává a aplikuje, dokonce se s ním hospodaří, je předmětem plánování, pracuje se s termínem management vědění (srov. Willke, 1998).

\subsection{Vědění coby veličina všem př́istupná, narůstající a podléhající kvalitativní proměně}

Suma vědění je pro jedince nezvládnutelná již od dob Goethových, tím není naše doba nová. Nová je v centrálním významu vědění pro všechny oblasti života, nikoliv jen pro výsostnou oblast vědy a výzkumu, v jeho enormním nárůstu, $\mathrm{v}$ rychlosti, s níž zastarává, a obrovským nárokem na vzdělání a neustálé další vzdělávání. Vědění však není jen jakýmsi útvarem, který pouze do všech směrů a bez ustání bobtná, nemá dynamiku pouze kvantitativní, vědění se proměňuje i kvalitativně a opouští překonané.

V současnosti je s postupující digitalizací velká část vědění masově přístupná. Př́ślovečný had se tak kouše do ocasu. Všichni mají nebo spíše mohou mít přístup ke všemu, což lze, jak se zdá, považovat za analogii k onomu prastavu, kdy ještě vědění nebylo uloženo $v$ knihách a nepříslušelo jen úzké privilegované skupině lidí, ale po generace se tradovalo. V nastalém vývoji lze tedy sice spatřovat určitou demokratizaci současného vědění, avšak jeho využití vyžaduje obrovskou erudici. Navíc, jak již bylo řečeno, velmi rychle zastarává, což jeho demokratizaci značně ztěžuje a činí ji namnoze nedosažitelnou. 
Je tedy namístě položit si otázku, co stojí v cestě k vědění, a tudíž i v cestě nejen $\mathrm{k}$ výhodám, které $\mathrm{z}$ něj plynou, ale jak se i dále ukáže, $\mathrm{v}$ cestě $\mathrm{k}$ úspěšnému fungování, tedy přežití ve společnosti vědění. Odpověd' je nasnadě: Přístup $\mathrm{k}$ vědění znesnadňuje neschopnost nebo málo vyvinutá schopnost orientace v informačních zdrojích, neschopnost informace vyhledat, rozlišit, které informace jsou relevantní a dostatečně spolehlivé, dále neschopnost správně je interpretovat a tvořivě s nimi naložit, neschopnost adaptovat se na změny, neschopnost se celoživotně učit, nedostatek kreativity. Cesta k odstranění těchto nedostatků je strastiplná a často velmi bolestná, což si každý, kdo si koupil nový mobilní telefon a dostal $\mathrm{k}$ němu návod o rozsahu slušného románu, jistě uvědomuje. Nutno dodat, že ubývá výrobků, u nichž by tomu tak nebylo.

Rychlost, s jakou se tento nárok vytvořil, je překvapivá. Ve dvacátých letech 20. století dokazoval americký psycholog E. L. Thorndike (1928) docilitu ${ }^{4}$ dospělých a o pár desítek let později je nastolen nárok učit se celoživotně, neustále se adaptovat na neustále se proměňující podmínky. A více než to: to, co Thorndike objevoval ve dvacátých letech jako možnost, je dnes postulováno dokonce jako jeden ze základních požadavků, který společnost vědění na každého jednotlivce klade. Nejpozději zde nalézáme první argument pro naši tezi, že vzdělávání a škola coby instituce, která pro společnost vzdělávání zajištuje, si v současné době zasluhují obzvláštní péči, protože jsou dokonce podmínkou přežití ve společnosti vědění.

\subsection{Vědění $=$ vzdělanost $=$ moudrost?}

Slovo vědění v každém zcela přirozeně vzbuzuje konotace spíše pozitivní, pod pojmem společnost vědění si rádi představíme společnost moudrých uvážlivých lidí, naplnění odvěkého ideálu lepších zítřků, odvěké víry v pokrok, dosažení osvíceneckého osvícení, vítězství rozumu atp. Jaká je však skutečnost? Je společnost vědění společností moudrosti respektive společností vzdělanosti? Zde si dovolme pochybovat. Podobně i rakouský filosof a kritik společnosti Konrad Paul Liessmann (2008) upozorňuje na háčky, které v sobě koncept společnosti vědění skrývá. Ačkoliv žijeme ve společnosti, která je nazývána společností vědění, nejsme dle Liessmanna o nic blíže pravdě a pochopení a nežijeme o nic lépe než naši předchůdci.

4 Možnost a schopnost se vůbec něčemu novému naučit. 
Český filosof Milan Machovec na adresu současné společnosti navíc říká:

Každý dnes musí mít maturitu, musí mít školy, být „vzdělaný“, ale vzdělanost se dnes chápe jen jako „dílna použitelnosti“. Učím se to, čím se budu živit a za co mi někdo zaplatí. Kdysi však definoval Komenský školu jako „dílnu lidskosti“. To je jeden z jeho nejslavnějších výroků o škole. Dnešní fetišizovaná společnost si jeho bustu sice dává nad průčelí mnoha škol, ale učitelé už nevedou žáky ke kráse, k pravdě, k hloubkám a hodnotám. (viz rozhovor Vidím obrovské úkoly...)

Německý kulturolog Nico Stehr zabývající se rovněž konceptem společnosti vědění zase poukazuje na fakt, že věda neprodukuje jistotu ve smyslu př́činných souvislostí, ale jen více či méně zdůvodněné hypotézy a pravděpodobnosti, v důsledku čehož: „Místo aby byla věda pramenem nepochybného vědění a jistoty, je věda takto především pramenem nejistoty a společenskopolitických problémů." (2002, s. 13) ${ }^{5}$

Německý sociolog Helmut Willke (1998, s. 8-9) upozorňuje na fakt, že data, která jsou vlastně nic neříkající údaje, nabývají na hodnotě a stávají se informacemi až po zasazení do relevantního kontextu a jejich hodnota je od různých kontextů prrímo odvislá. Takto postuluje jako problém i otázku výměny informací, nebot' tyto jsou zasazovány vždy do nestejných systémů, jednotlivé systémy mají totiž odlišná kritéria relevantnosti. My díky tomu dospíváme k závěru, že nelze očekávat, že je-li technicky možné získat informace z opačného konce světa či je tam odeslat, pak z toho může vzniknout oboustranné porozumění, či dokonce odstranění rozporů, globálních nerovností a globálních problémů, které lidstvo sužují.

Je zřejmé, že jednotlivé fenomény společnosti vědění přinášejí jak šance, tak také úskalí (viz tabulka 1).

5 „Statt Quelle von gesichertem Wissen und Gewissheit zu sein, ist Wissenschaft damit vor allem Quelle von Ungewissheit und gesellschaftspolitischen Problemen." (překlad: autorka) 
Tabulka 1

Šance a úskalí jednotlivých fenoménů společnosti vědění

\begin{tabular}{|c|c|c|}
\hline & Šance & Úskalí \\
\hline $\begin{array}{l}\text { Demokratizace } \\
\text { vědění }\end{array}$ & $\begin{array}{l}\text { Vědění přístupné } \\
\text { široké veřejnosti }\end{array}$ & $\begin{array}{l}\text { Pro přístup k němu a jeho uplatnění nutnost } \\
\text { vhodné edukace }\end{array}$ \\
\hline $\begin{array}{l}\text { Internacionalizace } \\
\text { vědění }\end{array}$ & $\begin{array}{l}\text { Rychlý a levný } \\
\text { přenos informací }\end{array}$ & $\begin{array}{l}\text { Obrovské množství informací, absence jistoty } \\
\text { a spolehlivosti těchto informací, nároky na } \\
\text { interkulturní porozumění }\end{array}$ \\
\hline $\begin{array}{l}\text { Demokratizace } \\
\text { naděje na úspěch }\end{array}$ & $\begin{array}{l}\text { Není zapotřebí } \\
\text { drahého kapitálu }\end{array}$ & $\begin{array}{l}\text { Nutnost celoživotního vzdělávání, neustálá } \\
\text { adaptace na změny, potřeba správného know-how, } \\
\text { nárok na psychickou odolnost }\end{array}$ \\
\hline
\end{tabular}

Je potřeba připustit, že vědění není ve společnosti vědění ztělesněním lásky $\mathrm{k}$ pravdě. Společnost vědění není společností moudrou. Vědění se může opět stát záležitostí hrstky vyvolených, nebude-li splněna podmínka vhodné edukace, a nebude sloužit žádnému pokroku, pravdě ani lásce $\mathrm{k}$ moudrosti, nebude-li splněna podmínka výchovy. Vědění bude ve skutečnosti tím, co umožňuje př́stup ke zdrojům, co je podmínkou ekonomického úspěchu. Společnost vědění je tedy na jedné straně zajisté šancí, na straně druhé však v sobě skrývá úskalí, na něž je potřeba upozorňovat.

Dle zmíněných kritiků současné společnosti nejsou vědění a věda zdrojem orientace a jistoty ve světě, jsou právě naopak zdrojem nejistoty. Doplňme o fakt, že jistou jistotou je jedině ta, že každý den může přinést změnu, že je potřeba „držet prst na tepu doby“ a umět se s onou změnou utkat. Dlužno dodat, že to není úkol vůbec snadný a nikdy nekončící proces adaptace vytváří na jedince i celou společnost značný tlak, díky němuž se opět do centra pozornosti dostává škola a celý systém vzdělávání. Mluvíme-li o společnosti vědění, mluvíme současně jedním dechem i o škole.

Přijměme pojem společnosti vědění bez jakéhokoli patosu coby označení výše popsaných určujících rysů naší doby a přijměme jej zejména $\mathrm{z}$ pozice školy, jejíž odvěkou úlohou není jen vzdělání ve smyslu kvalifikace (Machovcovy použitelnosti) pro určitou profesi, ale i výchova - kultivace, jako impuls a důvod k zamyšlení. Jako impuls k přemýšlení chápejme i výše uvedenou společenskou kritiku. 


\section{3 Člověk, škola a učitel v konfrontaci se společností vědění}

\section{1 Člověk ve světě práce společnosti vědění}

Člověk se v pracovním světě společnosti vědění již nestává „majitelem“ vědomostí, dovedností a rutiny, která by mu umožňovala vykonávat danou práci přibližně stejným způsobem po většinu produktivního života a vytvářela jeho společenský status, jak tomu bylo ještě v prvních dvou třetinách minulého století. Tím, že člověk získá pro určitou práci kvalifikaci - tedy potřebné vysvědčení, nezískává tím zakonzervovaný přístup k trvalému a jistému př́ijmu. Ani získání vysokoškolského diplomu není absolutní zárukou profesního úspěchu (srov. Ryška \& Zelenka, 2011, s. 90-92).

Člověk je nucen adaptovat se na nový charakter práce, nové informace a neustálou změnu technologií, musí se doškolovat, zaučovat s novými přístroji, nebo dokonce získat kvalifikaci zcela jinou. Willke (1998, s. 20 a další) označil nový druh práce ve společnosti vědění termínem Wissensarbeit (práce založená na vědění). Je to dle něj jediná možnost pro země prvního světa, které nemohou co do nákladů na manuální práci konkurovat zemím druhého a třetího světa, kam se tato práce přesouvá. Práce založená na vědění představuje sice vysoké náklady na vzdělávací systém, ty však mají svoji ekonomickou návratnost $v$ inovacích a obchodních nápadech. Základem konkurenceschopnosti firem je dle Willkeho jejich transformace na inteligentní organizace, které budou vykazovat schopnost vědění produkovat, využívat, budou schopny se učit a součástí těchto schopností a současně cílem bude schopnost inovativnosti.

Firmy na novou situaci již reagují. Uvědomění si potřeby neustálého vzdělávání na firemní úrovni je všudypř́ítomné. Vzdělání je prostředkem k rozvoji lidských zdrojů. Hojně se dnes např. hledají v pracovních nabídkách „specialisté vzdělávání", ačkoliv v našem školském systému takovou kvalifikaci vůbec získat nelze. Trh práce je zde tedy, jak se zdá, o krok napřed před školským systémem.

Jak bylo řečeno: člověk je ve společnosti vědění konfrontován s neustávajícími změnami, na něž se musí adaptovat, je nucen se neustále učit. Moderní technika sice nahradila monotónní či těžkou práci, počítače již dávno vnikly do všech kanceláří, institucí a škol, avšak stroje zastarávají, vyměňují se pro- 
gramy atp. Uvedené skutečnosti vytvářejí extrémní tlak, kterému nedokáže odolat každý. To má namnoze společenské důsledky (nezaměstnanost a s ní související negativní společenské jevy) i důsledky zdravotní (nárůst rozvoje psychosomatických onemocnění, úzkostných poruch, depresí, závislostí). Vzniká velký nárok na flexibilitu. Němečtí sociologové U. Beck a E. Beck-Gernsheim (2011, s. 74-75) hovoří o ničivém vlivu tohoto nároku na flexibilitu, který se pojí i s nárokem na mobilitu, na klasicky chápanou rodinu. Osobní i pracovní život se přesouvá do laptopu.

Zhruba pětina obyvatelstva se $s$ nároky doby zcela vyrovnat nedokáže a není schopna se na společnosti vědění plně podílet (srov. Willke, 2000, s. 256-257). Greger a Černý upozorňují na stratifikaci společnosti a uvádějí:

... koncepce společnosti vědění se sice tváŕí jako společnost všech, jako společnost, vekteréžijí/budoužít všichni. Ve skutečnosti však relevantním způsobem vypovídá pouze o jednom, maximálně dvou horních sociálních segmentech, jichž se logika a principy společnosti vědění bezprostředně týkají. Zbylá část obyvatelstva na společnosti vědění vlastně neparticipuje (či pouze zprostředkovaně, nepř́mo) a je z ní trvale vylučována. (2007, s. 27)

I v této souvislosti se musí opět do centra pozornosti dostat škola, coby instituce, která má na nové podmínky ve světě práce připravovat a bránit tak nepříznivé společenské stratifikaci.

\section{2 Škola a učitel ve společnosti vědění, otázky a odpovědi}

Položme si nejprve otázku, co v nových podmínkách od školy vlastně chceme? Škola je fenomén působící na více rovinách. Škola zásadním způsobem determinovala a determinuje celý náš individuální život jak horizontálně, tak vertikálně. Je však také kolektivním fenoménem, souborem živoucích organismů svého druhu, sociálních jednotek, komunit fungujících do jisté míry izolovaně, ale nacházejících se ve vzájemné interakci a v interakci s dalšími sociálními jednotkami jako je rodina, obec a stát, do jehož právního rámce jsou zasazeny. V současném globalizovaném světě však ani úroveň státní není úrovní, na níž by se bylo možno v uvažování o škole v kontextu společnosti vědění zastavit. Školu je nutné vnímat v celosvětovém horizontu, v němž je bez přehánění klíčovým faktorem, uvážíme-li, že spolu se společenskými kritiky škole ukládáme výchovu k odpovědnosti za svět a za řešení globálních problémů. Efektivní fungování na mikrorovině jedné konkrétní školy, třídy, dvojice učitel-žák tedy nemá jen důsledky pro individuum, ale i pro celou 
společnost, nebot' vědění je ve společnosti vědění zároveň prostředkem i cílem a vědění ve smyslu cíle si lze představit právě jako směřování k moudrosti a odpovědnosti za svět.

Co si lze pod oním efektivním fungováním ve speciálních podmínkách společnosti vědění představit? Společnost vědění je společností, v níž klíčovou roli hrají zejména inovace, kreativita, schopnost komunikace, kooperace, schopnost adaptovat se na změny, umění a ochota učit se - tedy lidský potenciál. To však nelze žádným způsobem nařídit shora a nelze to ani běžným způsobem naučit. Kompetence, které si společnost vědění žádá, nejsou plně sdělitelné slovy a obrazy, nelze je vyčíst $\mathrm{z}$ knih, jsou v těsném sepětí s praxí, s lidským jednáním.

Klíčové kompetence ve smyslu cíle školního vzdělávání jsou cíli nejobecnějšími (srov. Píšová et al., 2011, s. 277-279), jsou všudypř́ítomnou vertikálou k horizontálnímu průběhu školní každodennosti. Učitelé žákům zprostředkovávají učivo jednotlivých předmětů. Osvojování učiva - obsahu vzdělávání - žáky, jehož výsledkem jsou znalosti, dovednosti a zkušenosti, však není cílem konečným. Lze je chápat jako postupný cíl a prostředek k dosažení klíčových kompetencí, které se v konfrontaci s učivem rozvíjejí, což je sice jednoduché vyjádření cíle, ale cesta $\mathrm{k}$ němu je značně nesnadná. Vyžaduje od učitelů komplexní nazírání na svoji vlastní praxi. Učitel musí mít na zřeteli kromě zprostředkování učiva vždy i jeho syntézu do funkčních komplexů, které umožňují zorientovat se v nových situacích a posléze jednat. Nechceme-li vychovávat jedince úspěšné pouze ve vědomostních televizních soutěžích či jinak jednostranně orientované, ale jedince schopné obstát v nových podmínkách společnosti vědění, je potřeba radikální přehodnocení paradigmatu směřujícího k transmisi co možná největšího množství faktů a překonání určitého konzervativizmu části učitelské veřejnosti, nebot' suma informací je v současné době nezměrná, jak jsme nastínili v kap. 2.2, a je potřeba umět se $\mathrm{v}$ nich zorientovat, naučit se $\mathrm{z}$ nich vytvářet vědění, a to pak žádoucím způsobem přeměnit $v$ lidskou praxi. Se změnou paradigmatu tedy souvisí i proměna role učitele. Z neomylného kazatele se stává facilitátor v konstruování vědění či manažer vědění svých žáků, avšak i svého vlastního, což lze rozvinout i do vyšších rovin směrem ke konstruování vědění celé školy a společnosti.

Do školy přichází dítě, které je přirozeně zvídavé, kreativní, zvyklé opatřovat si své vlastní vědění a tento svůj obraz světa revidovat, reinterpretovat, kdy- 
koliv se setká s řešením nového problému, které dosavadní vědění zpochybní. Dítě je zvyklé klást otázky, hledat odpovědi. Dítě také přirozeně rozlišuje mezi dobrým a zlým. Úkol školy není o nic menší ani větší než toto vše zachovat, rozvinout a přeměnit v celoživotní zvyk, v celoživotní hledačství, tvoření, konstruování vědění. Nakolik to zní jednoduše, je to úkol enormní.

P. Struck ve své knize Die Schule der Zukunft: Von der Belehrungsanstalt zur Lernwerkstatt (1996) mluví v samotném názvu o nutné změně Belehrungsanstalt (ústav ponaučování) v Lernwerkstatt (dílnu učení) ${ }^{6}$. Dílna je místo, kde se stále něco děje, kde se neustále pracuje. Struckův pojem navozuje představu vzdělání coby dynamického otevřeného neustávajícího procesu, na němž se také neustále pracuje - tedy vzdělávání. My si jej zde vypůjčíme a přejmenujeme jej z logiky zavedených pojmů na dílnu vědění. Pojmem dílny vědění chceme evokovat představu místa, kde učitel nestojí oproti žákủm, kterým předává vědění - ponaučuje, ale je jakýmsi dílenským mistrem, který svým svěřencům pomáhá, radí, asistuje v jejich vlastním úsilí o konstruování vědění, sám však také pracuje na konstrukci svého vlastního vědění, nebot' společně s žáky vyhledává a ověřuje nejvhodnější postupy. Obraz dílny vyvolává představu žádoucí kooperace, osvobozuje učitele od mýtu vševědství a neomylnosti. Dílenský mistr přistupuje ke svým svěřencům individuálně, respektuje jejich osobní zvláštnosti a tempo, diskutuje s nimi, je ochoten se současně s nimi přiučit, pomáhá žákům získat odstup od jejich práce, učí je sebehodnocení atp. Tato metafora vystihuje podstatu toho, co se od školy ve společnosti vědění vlastně očekává a co je v konečném důsledku vlastně nezbytnou podmínkou přežití ve společnosti vědění, nikoliv jen jakýmsi humanistickým ideálem.

Pohlédněme nyní na věc $\mathrm{z}$ druhého břehu: $\mathrm{S}$ ohledem na náročnost úkolů, kterými je škola ze strany společnosti zahrnuta, by tedy měla požívat také tomu odpovídající vážnosti a péče. Je tomu v současné době však skutečně tak? Jedním z mála počitatelných ukazatelů jsou finanční prostředky, které stát na své školství vynakládá. Ve studii České školství v mezinárodním srovnání sice čteme, že vzdělání je nejlepší ochranou před nezaměstnaností, avšak tamtéž čteme také, že země OECD na primární, sekundární a terciární vzdělávání vydaly v roce 2009 v průměru 6,1\% kolektivního HDP, v České republice to bylo jen 4,5 \% (Kleňhová, Štastnová, \& Cibulková, 2011, s. 70-74). Tento

6 Srov. Machovec (viz rozhovor Vidím obrovské úkoly... ), Komenský (1948, s. 72). Opět se nám vrací obraz dílny. 
ukazatel svědčí pro spíše zápornou odpověd'. Společnost vědění sice školu coby centrální instituci, jak jsme výše nastínili, vnímá, avšak nepodporuje ji tak, jak by se slušelo a bylo by moudré.

Za další ukazatel můžeme považovat postavení učitelů v současné společnosti: Zdá se nám, že se dnes učitelé nacházejí pod velkým tlakem. Společností je jim uloženo sumu poznání svého oboru nejen vstřebat a celoživotně vstřebávat, ale ještě ji zprostředkovat, přičemž i způsob onoho zprostředkování podléhá rychlému vývoji. To vše za nízké finanční ohodnocení, které je jedním z momentů určujících společenský status dnešního učitele. Ve společnosti dle našeho názoru přetrvává archaická představa o učiteli, pro něhož je povolání posláním, které je vykonáváno ponejvíce $\mathrm{z}$ entuziasmu a lásky k bližnímu, nikoliv však profesí. Učitel je altruistou, jemuž ve společnosti náleží sice úcta ${ }^{7}$, nikoliv však vysoce specializovaným a patřičně odměňovaným odborníkem v oboru, který je pro společnost vědění klíčový.

Pro jasnější představu uved'me ještě, že učitelé v České republice pobírali $\mathrm{v}$ roce 2009 cca $50 \%$ platu zaměstnance ve věku 25-64 let, který pracuje $\mathrm{v}$ jiném oboru a je také vysokoškolsky vzdělán, což výrazně negativně ovlivňuje motivaci mladých lidí pro studium učitelství. Platy českých učitelů v nižším sekundárním vzdělávání byly v roce 2009 z 34 hodnocených zemí na 28. místě, hluboko pod průměrem zemí OECD, mezi Mexikem a Chile. Za Českou republikou se umístilo již zmíněné Chile, Polsko, Estonsko, Mad'arsko, Slovensko a Indonésie. Platy během kariéry v České republice učitelům rostou jen minimálně, i již zmínění chilští učitelé končí kariéru s vyšším platem než učitelé čeští, přičemž počet odučených hodin přibližně odpovídá průměru v zemích OECD. To má pochopitelně důsledky pro motivaci během profesního života, častý syndrom vyhoření atp. (Kleňhová, Št’astnová, \& Cibulková, 2011, s. 132-144).

Ukazuje se nám, že učitel je ve společnosti vědění jakoby dvojnásobně zespolečenštěn, je nucen všem jejím nárokům jednak sám čelit a jednak je jejím konstitutivním aktérem eminentní důležitosti zahrnutým nejvážnějšími úkoly. Jeho role je vnímána jako klíčová, požívá společenského uznání, nikoliv však tomu odpovídajícího finančního ohodnocení, které je jedním ze znaků pro uznání sociálního statusu specialisty. Hodnocení tohoto ukazatele tedy vyznívá rovněž více než ambivalentně.

7 Učitelské povolání se v žebřričcích prestiže jednotlivých profesí v sociologických šetřeních umistuje tradičně na předních příčkách (srov. Tuček \& Machonin, 1993). 


\section{Kritika školy odbornou i laickou veřejností - bod zlomu}

Pokusme se nyní nastínit, jaký je současný stav naší školy v očích laické i odborné veřejnosti a jak se s otázkou potřeby změn vyrovnává současný pedagogický diskurs zabývající se školou z úhlu pohledu společnosti vědění.

\subsection{Kritika školy a otázka její oprávněnosti}

$\mathrm{Z}$ médií takřka denně zaznívá, že česká škola nevede k samostatnosti, je kritizována propast mezi školou a praxí, zaostávání za vědou a výzkumem, ustrnutí v tradici předávání velkého množství faktů, s nimiž žáci nedokážou tvořivě nakládat, atp. Škole je vytýkáno, že nepřipravuje na pracovní svět současnosti, ale minulosti. V článku Většina českých středoškoláků se neumí učit (Scio, 2009) je např. kritizována převládající monotónní frontální výuka a nároky na memorování. Dủkazem nespokojenosti rodičů se stavem českého školství je mimo jiné i vznik řady alternativních škol, které jsou rodiči stále vyhledávány. V. Klaus ml. uvádí v rozhovoru Dobrou školu dělají žáci a učitelé, který poskytl serveru lidovky.cz u př́ležitosti založení nové soukromé základní školy Nový PORG nabízející alternativní metody, individuální přístup a rozšířenou výuku jazyků: „Až bude konkurence státních škol lepší a navíc zadarmo, tak okamžitě zkrachujeme..." (Cihelka, 2008).

Výzkumy OECD PISA z let 2000 (Straková et al., 2002), 2003 (Palečková \& Tomášek, 2005) a 2006 (Palečková et al., 2007), které se postupně ve třech fázích zabývaly čtenářskou, matematickou a přírodovědnou gramotností českých žáků základních škol a gymnázií ve věku patnácti let, ukázaly, že si čeští žáci dokázali osvojit nadprůměrné množství přírodovědných poznatků a teorií, neumějí o nich ale dostatečně dobře a samostatně uvažovat a zkoumat je. V oblasti čtenářské gramotnosti činí českým žákům potíže porozumění a hodnocení textu a byly konstatovány i rezervy v aplikaci matematických postupů v reálných situacích. První fáze druhého cyklu šetření PISA v roce 2009 (Palečková, Tomášek, \& Basl, 2010), která se zaměřovala zejména na čtenářskou gramotnost žáků, ukázala, že $\mathrm{v}$ čtenářské gramotnosti došlo u českých žáků v porovnání s rokem 2000 v oblasti porozumění a hodnocení textu ještě $\mathrm{k}$ významnému zhoršení.

Nespokojenost se stavem školství však není jen českou specialitou: Krumm (1986) kritizuje převládající „Dozieren“ - přednášení, předkládání sumy 
vědomostí školou, která je poplatná tradici sahající až do antiky, oproti žádoucímu „Kommunizieren“.

Kritické výtky vůči škole dobře vystihuje následující teze německých pedagogů:

...v době, kdy je vědění $\mathrm{v}$ celé své komplexnosti $\mathrm{k}$ dispozici, je důležitější vědět, jak se člověk $\mathrm{k}$ vědění nutnému pro definování specifického problému dostane, než disponovat většinou malým a neúplným segmentem vědění, které je $\mathrm{v}$ době svého možného využití již zastaralé, př́íp. neupotřebitelné. ${ }^{8}$ (Rüschoff \& Wolff, 1999, s. 19)

Na druhé straně lze namítnout, že společenská kritika školství je obdobným fenoménem jako odvěká lamentace nad zkaženou mladou generací. Rüschoff a Wolff také zdůrazňují skutečnost, že společnost sice volá po reformách, nedostatečně však formuluje, jaké změny si vlastně přeje. Tato tendence se, jak jsme již naznačili, často vtěluje do prázdných proklamací a hesel různých politických i školských dokumentů.

Prakticky žádná společnost není spokojena se stavem svého školství, už Sókratés byl popraven, protože coby učitel kazil mládež. Z tohoto pohledu by se škola v krizi nacházela trvale, navíc by bylo možno argumentovat, že škola musí logicky pokulhávat za vývojem společnosti a vědeckým výzkumem, nebot' je tradičně chápána jako odraz obojího. Takové pojetí školy by však $\mathrm{s}$ ohledem na výše řečené bylo $\mathrm{v}$ rozporu s konceptem společnosti vědění, dle něhož škola nestojí na okraji společnosti, ale je její nedílnou a ústřední součástí, nikoliv jejím pouhým, navíc opožděným odrazem. V této skutečnosti je nárok na změny zajisté založen a je potřeba se proti pojetí školy coby pouhého odrazu skutečnosti důrazně ohradit.

\subsection{Bod zlomu}

Současný pedagogický diskurs směrem ke společnosti vědění žongluje s pojmy naznačujícími potřebu více či méně radikálních změn jako bod obratu, vzdělávání na křižovatce (Maňák, 2009, s. 13), zásadní přelom v pojetí vzdělávání (Walterová, 2004, s. 32). Young (1998) a Greger a Černý (2007)

... in einer Zeit, in der das Wissen in seiner Komplexität zur Verfügung steht, ist es wichtiger $\mathrm{zu}$ wissen, wie man an das für eine spezifische Aufgabenstellung erforderliche Wissen herankommt, als über ein meist kleines und unvollständiges Wissenssegment zu verfügen, das zum Zeitpunkt seiner möglichen Anwendung schon veraltet bzw. unbrauchbar geworden ist. (překlad: autorka) 
uvažují o kurikulu budoucnosti, respektive kurikulu pro společnost vědění. U různých autorů se vracejí tatáž či velmi podobná témata, která jsou opakovaně považována za problematická, což je dalším neklamným signálem pro nutnost změn. Pozastavme se nyní u několika autorů a témat.

Walterová (2004) zdůrazňuje roli školy v přiblížení vědění jeho možné aplikaci v praxi, jako klíčové kompetence pro společnost vědění chápe identifikování problémů, systémové a abstraktní myšlení, schopnost práce se symboly a $\mathrm{v}$ neposlední řadě schopnost nést odpovědnost za zásadní rozhodnutí. Rádi souhlasíme s její tezí: „Společenský a ekonomický rozvoj je závislý na poznávacích procesech, jejich výsledcích a efektivním využívání těchto výsledků." (s. 33)

Young (1998) se zabývá obsahem vzdělávání - kurikulem, rozlišuje mezi kurikulem minulosti a kurikulem budoucnosti, není však pro radikální účtování s minulostí, vyslovuje se naproti tomu pro zachování kontinuity s minulostí a hledání správného poměru mezi předáváním dosavadního vědění a učením pro budoucnost, v čemž spatřuje podobně jako Walterová (2004) dosažení většího sepětí s praxí. Young klade důraz na provázanost oborů oproti jejich dřívějšímu striktnímu oddělování, na vlastní aktivitu žáků při utváření svého vlastního vědění, na relevantnost vědění pro řešení každodenních problémů.

Greger a Černý (2007) mimo jiné formulují trendy, ke kterým by mělo vzdělávání ve společnosti vědění směřovat: trend integrace poznatků, trend sbližování všeobecného a odborného vzdělávání, trend obohacování kurikula o nová témata. Pozastavují se nad tím, jak tyto trendy hodnotí společnost. Zatímco trend obohacování kurikula o nová témata (např. z oblasti ICT nebo ekologie) je přijímán pozitivně, trend sbližování všeobecného a odborného vzdělávání vytváří obavu $\mathrm{z}$ produkce nezaměstnatelných všeobecně vzdělaných absolventů. Greger a Černý naproti tomu vyjadřují pochybnost, zda je přidávání nových témat vůbec v možnostech školy, a vyslovují obavu $\mathrm{z}$ toho, že by tato praxe mohla sklouznout $\mathrm{k}$ „lepení záplat na starý kabát“. Cestu vidí v reformulaci, v novém promýšlení cílů, obsahů, forem a metod vzdělávání.

Maňák (2009, s. 11-20) vidí jako zásadní úkol školy formování osobnosti coby tvůrce společnosti, zdůrazňuje nebezpečí, která představuje velké množství informací, které je neustále generováno, v němž se však nikdo nedovede 
zorientovat. Vycit'uje problémy globálního charakteru a relativismus hodnot, který se v současné společnosti rozmáhá. Tvrdí, že věda a technika sice dosahují úspěchů, ty však jsou ve službách trhu a nesměřují k řešení aktuálních problémů. Souhlasíme s ním, že škola má ve společnosti vědění pro ni vlastně sebezáchovný charakter, přičemž hlavní úkoly pro budoucnost lze dle Maňáka (2009, s. 19) shrnout takto: rozvoj žáka coby integrované osobnosti vybavené nezbytnými morálními zásadami a nikoliv pouze nezbytnými informacemi pro orientaci ve světě, sjednocování poznatků a jejich účelný výběr pro žádoucí nasměrování vědění, vytvoření nových strukturních systémů, propojování oborů, zvyšování zodpovědnosti a tvůrčí samostatnostiučitelů ${ }^{9}$, podporování samostatnosti žáků, užíváníaktivizačních výukových metod. Škola se pak má stát organickým komunitním zařízením, centrem kulturního dění, badatelskou komunitou a místem, které bude všem generacím poskytovat podněty pro další rozvoj - centrem pro vzdělávání celé společnosti. Pro školu pak žádá všestrannou celospolečenskou podporu a nikoliv jen prázdné proklamace.

Je zřejmé, že změny jsou $\mathrm{v}$ očích veřejnosti laické i odborné vnímané jako naprostá nutnost. Škola ve společnosti vědění stojí před náročnými úkoly a je jejím neuralgickým bodem. Dodejme však také, že zatímco mnohé, co již do české školské praxe vstoupilo, požadavky společnosti vědění respektuje: např. rámcové vzdělávací programy,kterézasazujídříveizolovanépředmětydo širších kontextů, umožňují zdůraznění mezipředmětových vazeb, projektové učení, případové studie, skupinové formy vyučování, které navozují situace z praxe, vedou k týmovému řešení problémů a sdílení znalostí (srov. Švec, 2009), dluh společnosti vědění vůči škole je stále nesplacen.

\section{Závěrem}

\subsection{Hlavní výzvy společnosti vědění vůči škole}

Komplexní proměnu společnosti ve společnost vědění lze konstatovat jako fakt. Žijeme ve společnosti vědění, at' už jí tak říkáme, nebo nikoliv, at' už chceme, či nechceme. Společnost se radikálně proměnila, vyvstaly nové požadavky, v jejichž centru je člověk.

9 Maňák (2009, s. 15-16) dobře vystihuje bolest českého školství, jež sice zavedlo rámcové vzdělávací programy, které $\mathrm{k}$ interdisciplinaritě směřují. Revoluce $\mathrm{v}$ hlavách českých učitelů však dosud dostatečně neproběhla, považuje ji však za naprosto nezbytnou. 
Ve společnosti vědění jde zejména o strategie a schopnosti. Jak již bylo řečeno, klíčovou kompetencí, které je potřeba dosáhnout, je umění učit se ústící v ideál sebevzdělávání. Další kompetence, které vyplývají z charakteru společnosti vědění, jsou schopnost opatřovat si informace, tvořivě s nimi nakládat, analyzovat je a činit závěry, schopnost metakognice, schopnost kritického myšlení, schopnost komunikovat, diskutovat, argumentovat a především schopnost adaptovat se na změny, schopnost spolupracovat - sociální kompetence. Člověk však musí být ve společnosti vědění schopen i sebevýchovy, aby získané vědění a kompetence upřel ve svém jednání tím správným směrem.

Ve společnosti vědění vzdělání není uzavřeným zakonzervovaným komplexem předaných znalostí a dovedností stvrzeným př́slušným vysvědčením či diplomem, které opravňují k výkonu nějaké přesně definované profese, celoživotní zárukou obživy, ale naopak živoucím otevřeným systémem, pro který je vhodnějším termínem termín vzdělávání akcentující jeho procesuálnost, neuzavřenost a komplexnost. Vzdělávání je celoživotním úkolem.

Škola má v plnění tohoto úkolu umožnit, ukázat a dodat potřebné nástroje, učinit ho pokud možno bezbolestným, samozřejmým. Škola má být ve společnosti vědění dílnou vědění, součástí praxe, která sama produkuje další vědění, má být respektovaným centrem společenského dění. Škola není ve společnosti vědění jen jakýmsi služebníkem, ale aktivní složkou ovlivňující celou společnost. Učitel se ve společnosti vědění má stát dílenským mistrem napomáhajícím žákům v jejich vlastní aktivitě, nikoliv neomylným kazatelem, současně má být však přijat coby expert těžící z mnoha vědních disciplín současně, respektovaný klíčový aktér.

Kurikulum pro společnost vědění má být otevřené, flexibilní, přístupné změnám, pružně reagující na individuální potřeby svých adresátů, splňující nárok interdisciplinarity s ohledem na provázanost jednotlivých oborů a internacionality s ohledem na internacionalizaci celé společnosti, respektovat potřeby praxe i nejnovější vědecký výzkum, obojí pak zasluhuje soustavnou reflexi a zkoumání.

\section{2 Škola společnosti - společnost škole}

Škola je ve společnosti vědění v roli prostředníka ukazujícího cesty k vědění, dějištěm ve smyslu Struckovy dílny učení a naší dílny vědění. Současně však přetrvává tradiční úloha školy coby instituce vytvářející kontinuitu s minu- 
lostí, zajišt'ující obecnou vzdělanost ${ }^{10}$ bez ohledu na její ekonomické využití, instituce, která má kultivující poslání. Úkolem školy ve společnosti vědění je vést nejen $\mathrm{k}$ sebevzdělávání ale i $\mathrm{k}$ sebevýchově. Tento úkol školy je ve společenské diskusi spíše upozad'ován zejména v postkomunistické zemi s živou vzpomínkou na jeho někdejší profanaci. Škole však nemá jít jen o zprostředkování takových kompetencí, které umožní obstát na trhu práce společnosti vědění, ale i o přiblížení se sokratovskému ideálu věčného hledačství pravdy, dobra a krásy, problematizování zdánlivě daného, které má za úkol a má i moc ochránit, jak dnes, tak od věků, před riziky jakékoli ideologie - případně tudíž i vyprázdněné ideologie společnosti vědění. Právě pro společnost vědění u vědomí jejích šancí i rizik je nezbytné zachování obou rovnocenných pilírů školy, jak vzdělávacího, tak výchovného.

Výzvu školy vůči společnosti by pak bylo možné formulovat jako apel směřující k uvědomění si faktu, že vzdělání, vědění a kreativita jsou vlastně nejen privátním kapitálem jednotlivce, ale kapitálem celé společnosti s přímou linkou ke zdrojům, což je ekonomickým př́nosem dobře prosperujícího školství společnosti. Osobní kvalita života a úspěch v zaměstnání jednotlivce jsou však př́mo závislé na úrovni jeho participace společenské, respektive politické, na úrovni proniknutí do společenských sítí, schopnosti kolektivní spolupráce, osobních morálních kvalitách. Výchova jedinců těchto kvalit je lidským př́nosem dobře prosperujícího školství společnosti - lidskou dimenzí společnosti vědění. Společnost si tedy musí uvědomit, že školství, kterému se po všech stránkách daří, je pro ni nejen obrovským př́nosem, ale s ohledem na výše řečené i podmínkou samotného přežití společnosti, a věnovat škole náležitou pozornost a konkrétní péči, nikoliv jen prázdná hesla.

\section{Literatura}

Beck, U., \& Beck-Gernsheim, U. (2011). Fernliebe. Berlin: Suhrkamp Verlag.

Bell, D. (1973). The coming of the post-industrial society. A venture in social forecasting. New York: Basic Books.

Cihelka, M. (2008). Dobrou školu dělají žáci a učitelé. In Lidovky.cz. Rozhovor s Václavem Klausem ml. Dostupné z http://www.lidovky.cz/dobrou-skolu-delaji-zaci-a-ucitele-drn-/ zpravy-domov.aspx?c=A080901_111258_ln_rozhovory_bat

10 Pojem vzdělání nahrazujeme pojmem vzdělávání s argumentem jeho neuzavřenosti a zde přidáváme ještě pojem „vzdělanosti“, který je třeba chápat jako jakési podhoubí, systém vědomostí a dovedností, $\mathrm{z}$ něhož mohou kompetence požadované společností vědění vyrůst a rozvíjet se. 
Dlouhodobý záměr vzdělávání a rozvoje vzdělávací soustavy ČR (2007). Praha: MŠMT. Dostupný zhttp://www.msmt.cz/ministerstvo/dlouhodoby-zamer-vzdelavani-a-rozvoje-vzdelavacisoustavy-cr

Drucker, P. (1969). The age of discontinuity: Guidelines to our changing society. New York: Harper \& Row.

Greger, D., \& Černý, K. (2007). Společnost vědění a kurikulum budoucnosti. Orbis scholae, 1(1), 21-39.

Klein, H. E. (1998). Offene Schule und Wissensgesellschaft - ein Gegensatz? Beitrag für die virtuellen Konferenz „Lernen und Bildung in der Wissensgesellschaft“ 11/1998. Dostupné z http://www.wissensgesellschaft.org/themen/bildung/offeneschule.pdf

Kleňhová, M., Št’astnová, P., \& Cibulková, P. (2011). České školství v mezinárodním srovnání. Stručné seznámení s vybranými ukazateli publikace OECD Education at a Glance 2011. Praha: Ústav pro informace ve vzdělávání.

Klusáček, K., Kučera, Z., \& Pazour, M. (2008). Bílá kniha výzkumu, vývoje a inovací v České republičce. Praha: Technologické centrum Akademie věd ČR. Dostupné z http://www. vyzkum.cz/storage/att/4CDC7DE24D131CB07C65FAA7D04B9418

Komenský, J. A. (1948). Didaktika velká. Brno: Komenium.

Kopecký, M. (2009). Společnost vědění. In J. Průcha (Ed.), Pedagogická encyklopedie (s. 34-38). Praha: Portál.

Krumm, H. J. (1986). Zielsprachliches und einheimisches Lehrverhalten aus der Sicht von Sprachlehrern. In J. Geringhausen (Ed.), Methodentransfer oder angepasste Unterrichtsformen? (s. 21-37). München: Goethe-Institut.

Liessmann, K. P. (2008). Teorie nevzdělanosti. Praha: Academia.

Maňák, J. (2009). Vzdělávání ve společnosti vědění. In T. Janík \& V. Švec, et al., K perspektivám školního vzdělávání (s. 11-20). Brno: Paido.

Matějů, P. et al. (2009). Bílá kniha terciárního vzdělávání. Praha: Ministerstvo školství, mládeže a tělovýchovy.

Národní Lisabonský program 2005-2008 (2005). In Národní programy reforem a integrované směry. Praha: MŠMT. Dostupné z http://www.msmt.cz/mezinarodni-vztahy/narodniprogramy-reforem-a-intgrovane-smery

Národní program reforem České republiky 2008-2010 (2008). In Národní programy reforem a integrované směry. Praha: MŠMT. Dostupné z http://www.msmt.cz/mezinarodni-vztahy/ narodni-programy-reforem-a-intgrovane-smery

Národní program rozvoje vzdělávání v České republice, Bílá kniha. (2001). Praha: Ústav pro informace ve vzdělávání.

OECD (2003). Knowledge management in the learning society. Paris: OECD Publishing.

Palečková, J., et al. (2007). Hlavní zjištění výzkumu PISA 2006. Praha: Ústav pro informace ve vzdělávání.

Palečková, J., \& Tomášek, V. (2005). Učení pro zítřek. Praha: Ústav pro informace ve vzdělávání.

Palečková, J., Tomášek, V., \& Basl, J. (2010). Hlavní zjištění výzkumu PISA 2009. Praha: Ústav pro informace ve vzdělávání.

Píšová, M., Kostková, K., Janík, T., Doulík, P., Hajdušková, L., Knecht, P., ... Vlček, P. (2011). Kurikulární reforma na gymnáziích. Př́ípadové studie tvorby kurikula. Praha: Výzkumný ústav pedagogický. 
Rüschoff, B., \& Wolff, D. (1999). Fremdsprachenlernen in der Wissensgesellschaft. Ismaning: Hueber.

Ryška, R., \& Zelenka, M. (2011). Charakteristiky vysokoškolského vzdělání a profesní úspěch. Orbis scholae, 5(1), 71-94.

Scio. (2009). Většina českých středoškoláků se neumí učit. In Novinky.cz. Dostupné z http:// www.novinky.cz/veda-skoly/vzdelavani/168267-vetsina-ceskych-stredoskolaku-seneumi-ucit.html

Stehr, N. (2002). Moderne Wissensgesellschaften. Bundeszentrale für politische Bildung. Dostupné z http://www.bpb.de/apuz/26052/moderne-wissensgesellschaften/

Straková, J., et al. (2002). Vědomosti a dovednosti pro život. Praha: Ústav pro informace ve vzdělávání.

Strategie rozvoje lidských zdrojů pro Českou republiku. (2003). In Evropský sociální fond $v$ ČR. Dostupné z http://www.esfcr.cz/file/3772

Struck, P. (1996). Die Schule der Zukunft: Von der Belehrungsanstalt zur Lernwerkstatt. Darmstadt: Wissenschaftliche Buchgesellschaft.

Švec, V. (2009). Sdílení znalostí ve školním prostředí. Pedagogická orientace, 19(2), 22-37.

Thorndike, E. L. (1928). Adult learning. New York: The Macmillan Company.

Tuček, M., \& Machonin, P. (1993). Prestiž povolání v České republice v roce 1992. Sociologický časopis, 29(3), 367-382.

UNESCO. (2005). Towards knowledge societies. Paris: UNESCO Publishing.

Veselý, A. (2004). Společnost vědění jako teoretický koncept. Sociologický časopis, 40(4), 433-446.

Vidím obrovské úkoly, ale nevidím lidi schopné řešitje. Rozhovor s Milanem Machovcem. Dostupné z http://www.sds.cz/search.php a http://www.sds.cz/docs/prectete/rozhovor/kra_mach. htm/.

Walterová, E. (2004). Úloha školy v rozvoji vzdělanosti. Brno: Paido.

Willke, H. (1998). Systemisches Wissensmanagement. Stuttgart: Lucius \& Lucius.

Willke, H. (2000). Společnost vědění. In A. Pongs (Ed.), V jaké společnosti vlastně žijeme? (s. 243-262). Praha: ISV.

Young, M. (1998). The curriculum of the future. London: Falmer Press.

\section{Autorka}

Mgr. Petra Valentová, Vysoká škola ekonomická v Praze, Fakulta mezinárodních vztahů,

Katedra německého jazyka, nám. W. Churchilla 4, 13067 Praha 3, e-mail: valentop@vse.cz

\section{The role of school in the knowledge society and the consequences of social changes for school}

Abstract: Knowledge society - a term denoting many theoretical approaches to understanding today's presence which has also become a part of many public 
documents. The goal of the article is to examine and summarize characteristic features exhibited by our presence which entitle this term to be used; it also brings the opinions of social critics - the critics of the knowledge society concept. It also contemplates the newly defined role of the man in the world of work and the consequences and new targets that follow from the knowledge society concept for school. At the same time, it indicates the responsibility of the society to school for the school is a central institution in the knowledge society but it does not always enjoy the adequate respect.

Keywords: knowledge society, education, school, new teacher's role

\section{Sociální studia 2/2012}

Druhé loňské číslo Sociálních studií je věnováno dítěti jako aktérovi v rámci rodiny i vzdělávacího systému. Obsahuje následující statě: Deti medzi emancipáciou a sociálnou využitel'nost’ou: nová sociológia detstva a „našepkaná emancipácia“ (O. Kaščák, B. Pupala), Nejdřív byli dinosauři a pak se narodila prababička aneb Chvála etnografie ve výzkumu dětí L. Jarkovská), „Mluví, jako kdyby byla fakt Češka“: Konstrukce národnosti/etnicity v promluvách dětí (K. Lišková), Mezilidské vztahy v rodině v percepci dětí mladšího školního věku (L. Stašová, H. Serbousková) a „Firma vydělává, děti se učí, žena je hodná a já jsem štastný." Představy dětí o budoucím životě (L. Slepičková). V časopise je rovněž otištěna výzkumná zpráva Příspěvek k hodnotám dnešních dětí (M. Bocan, T. Machalík). 